\title{
RURAL QUALITY OF LIFE - POVERTY, SATISFACTION AND OPPORTUNITY DEPRIVATION IN DIFFERENT TYPES OF RURAL TERRITORIES
}

\author{
Josef Bernard ${ }^{1}$
}

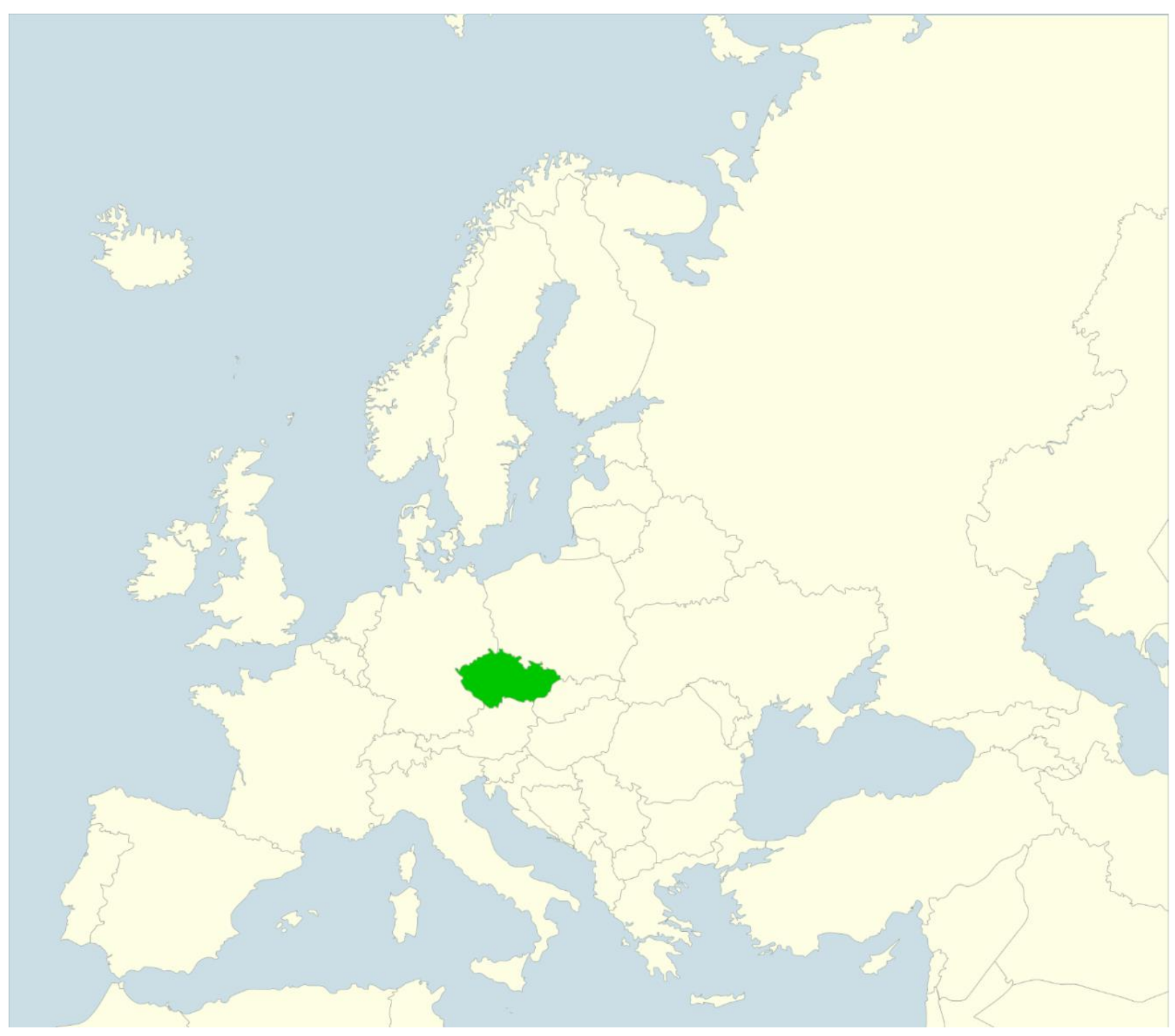

${ }^{1}$ PhDr. Josef Bernard, Ph.D.; Institute of Sociology, Czech Academy of Sciences, Jilská 1, 110 00, Praha 1; e-mail: josef.bernard@soc.cas.cz 
Abstract: This article contributes to the rural-urban quality of life comparison issue by investigating territorial differences in quality of life using indices of poverty, satisfaction and opportunity deprivation. The article introduces three innovative elements. First, rural-urban differences are analysed alongside with the within-rural differentiation; second, two distinct spatial patterns of different forms of rural territorial disadvantage are introduced; third, the net-effect of the residential environment is assessed. Empirical results, based on survey data, show increased opportunity deprivation in rural areas, which however is not accompanied by decreased community satisfaction. For the most indices, within-rural differences proved larger than the difference between urban and rural areas.

Keywords: quality of life, rural, periphery, disadvantage, opportunity deprivation, poverty, Czech Republic

Abstrakt: Článek je příspěvkem k tématu komparace kvality života na venkově a ve městech. Zkoumá územní rozdíly $v$ kvalitě života $s$ použitím indexů chudoby, spokojenosti a príležitostí. Do výzkumu tohoto tématu přináší tři inovativní prvky. Za prvé, rozdíly mezi venkovem a městy jsou analyzovány spolu s diferenciací uvnitř venkova; za druhé představuje a analyticky využívá dva odlišné prostorové vzorce různých forem venkovského znevýhodnění; za třetí, hodnotí čistý efekt rezidenčního prostředí. Empirické výsledky založené na dotazníkových datech ukazují na problém deprivace přiležitostí ve venkovských oblastech, který však není doprovázen poklesem spokojenosti s lokalitou. Pro většinu ukazatelů se rozdíly v rámci venkovských oblastí ukázaly být větší než rozdíly mezi městskými a venkovskými oblastmi.

Klíčová slova: kvalita života, venkov, venkovská periferie, znevýhodnění, deprivace přiležitostí, chudoba, Česko

\section{Introduction}

The question whether city life is preferable to living in the countryside or the other way round is a long-term part of the popular discourse. It recently experienced an unexpected revival in many countries in relation to the electoral outcomes. A territorial divide became apparent between voters in metropolitan areas on one hand and voters in rural areas in the U.S., U.K. or France. They were in particular rural areas, where anti-establishment and populist parties gained most support as a result of widely perceived marginalisation. In Czechia, despite the absence of a clear rural-urban electoral cleavage, a similar argumentation about rural marginalisation appeared recently in the public administration, claiming that rural areas do not offer living conditions comparable to towns, suffer from a limited "viability" and therefore lose population (Ministry of Agriculture 2016).

The debate about urban-rural disparities in living conditions and, broadly speaking, in quality of life, is part of a broader stream of ideas about the residential aspects of life, which searches answers to questions whether, to what extent and how individual lives are influenced by the residential environment. Many studies focused particularly on inequalities and disadvantages resulting from the residential environment, predominantly in urban neighbourhoods (see the vivid debate on neighbourhood effects (Dietz 2002; Sharkey, Faber 2014), but sometimes with focus on rural areas and rural-urban disparities as well (Cotter 2002, Fisher 2005, Weber et al 2005). In Czechia, this debate was fuelled most importantly by Musil and Müller's (2008) study on internal peripheries. They argued that there are disadvantaged, predominantly rural territories, located mostly at regional borders, whose inhabitants suffer from a limited job offer, dilapidated public infrastructure and constrained transport options, which makes them face decreased quality of life and an increased risk of social exclusion. The issue of rural quality of life and particularly the thesis about low quality of life in disadvantaged peripheral areas in Czechia has been 
repeatedly empirically investigated in form of qualitative case studies. The main struggles faced by the inhabitants of peripheries have been described as a shortage of qualified employment opportunities, poor transport access, underdeveloped civic infrastructure, and declining civic life (Ouředníček et al. 2011, Temelová et al. 2011). Bernard et al (2016) uncovered cumulative causation of disadvantage in rural areas in which individual vulnerabilities intersect and multiplicate with poorly developed opportunity structures. Rather, quantitative analyses of the issue have been sparse. Pospěch et al (2009) have compared statistically selected QOL indicators between rural and urban areas, concluding that there are actually low differences between them. They argue that the high urbanisation level of Czechia and a solid interconnection of rural areas into the networked contemporary society diminishes urban-rural differences. Similarly, Chromý et al (2011) found little regional differences in evaluations of living conditions in rural areas by representatives of rural communities.

The goal of this article is to investigate the issue of quality of life in rural areas further and to gain a more detailed picture of the situation by introducing three innovative elements: First, I argue that the rural-urban dichotomy masks many aspects of within-rural territorial differentiation in quality of life and that there are important differences between disadvantaged peripheral rural areas and non-peripheral rural areas. Second, I argue that it is an oversimplification to speak about one uniform type of disadvantaged rural peripheries. Instead, several patterns of different forms of disadvantage exist in rural areas, creating different spatial patterns and impacting quality of life in different ways. Third, using individual-level survey data, I distinguish the net-effect of the residential environment from effects based on individual personal traits and the household composition.

The article is structured as follows. In the first part, the issue of rural quality of life and rural disadvantage is introduced. In the second part, the delimitation of disadvantaged peripheral areas in Czechia is introduced, based on a set of area-level indicators. Thirdly, differences in various quality of life indicators between peripheral and non-peripheral areas are analysed and the neteffects of living in peripheries are assessed.

\section{Approaches to investigate rural quality of life and aspects of rural disadvantage}

There have been several approaches how to conceptualise and measure the specifics of rural quality of life and more specifically, social inequalities related to the urban-rural divide and rural forms of disadvantage. An important group of studies have focused on urban-rural comparisons of selected indicators related to social inequalities, in particular on poverty and deprivation indices (Cotter 2002; Fisher 2005; Weber et al 2005; Lichter, Johnson 2007). The so called "rural effect" literature, based predominantly in the U.S. context, asks whether there is something about rural places that makes poverty, deprivation or other forms of disadvantage more likely. Rural living has been described as an independent contextual factor contributing to increased levels of disadvantage and poverty. For example, Cotter (2002) argues that limited labour market opportunities in U.S. non-metropolitan areas affect both the likelihood of being poor and the degree to which employment reduces a household's chances of falling into poverty. In his view, increased levels of rural poverty can be explained apart from household-level characteristics as a consequence of labour shortage and the dominance of low-pay job sectors in rural areas. In European countries, the situation seems more complicated due to huge differences in the direction and extent of urban-rural disparities. Whereas in some countries like the U.K, France or Belgium, rural areas experience even slightly lower poverty levels compared to cities (Eurostat 2015), particularly in eastern and southern European countries, the countryside is markedly disadvantaged in terms of poverty, deprivation and well-being compared to cities (Shucksmith et al 2009). Interestingly enough, the reasons of these disparities remain widely unexplored.

In a similar manner, albeit with different outcomes, some studies focused on the comparison of subjective well-being and satisfaction levels between urban and rural localities. In the U.S., like in some other countries, an urban-rural happiness gradient has been observed that rises from lowest levels in large cities to highest levels in the rural periphery (Berry, Okulicz-Kozaryn 2011; Winters 2017) Similarly, Requena (2016) found higher subjective well-being in rural areas 
compared to cities, albeit just in economically more developed countries, while in less developed countries, the rural environment cannot compete with urban resources for creating subjective well-being. Migheli (2017) confirmed the negative effect of urbanisation levels on life satisfaction also in European countries. He argues however, that the effect is less pronounced for welleducated who benefit more from the urban environment. There seems to be a contradiction in findings of studies using objective indicators of lower quality of life, like poverty and deprivation and studies using subjective expressions of satisfaction and happiness. Whereas in the former ones, in most countries the countryside ends up worse than cities, in the latter ones, an almost universally higher indices of quality of life in the countryside have been reported.

Another stream of inquiry has proposed that rural residents experience different forms of disadvantage and deprivation than their urban counterparts. The difference between rural and urban disadvantage is thus more of a qualitative than merely a quantitative nature. Compared to densely inhabited and relatively well spatially penetrable cities, in the more sparsely populated rural areas where reaching various opportunities is frequently related to traveling, mobility has been found as a crucial aspect of well-being. Analogically, limited spatial mobility is in rural areas a central aspect of deprivation. The widely cited Shaw's rural deprivation model (Shaw 1979) conceptualised the specifics of rural deprivation in the U.K. as opportunity deprivation combined and reinforced frequently with mobility deprivation, i.e., the non-existence or loss of jobs and services in rural areas and their inaccessibility by important parts of the rural population. Constrained access to various amenities and jobs has been conceptualised also in U.S. studies as an important factor of rural disadvantage and deprivation. Tickamyer and Duncan described poor rural communities in the U.S. as places which "lack stable employment, opportunities for mobility, investment in the community and diversity in the economy and social institutions" (Tickamyer and Duncan 1990: 67). According to this research stream, the urban-rural gap in quality of life is far less connected to economic aspects of life, but is based on limited opportunity accessibility, which, of course, interrelates in individual cases with economic hardship.

The existence of specific forms of rural disadvantage has been proposed also by scholars dealing with area-level deprivation indicators. Classical deprivation indices like the Townsend index (Townsend 1987) use a unidimensional deprivation index based on deprivation forms typically particular for segregated urban neighbourhoods (e.g., limited car ownership, overcrowding, unemployment, not owner-occupied residence). Measured that way, most rural areas show relatively modest deprivation levels. In contrast to it, some newer approaches understand deprivation as a multi-dimensional concept that includes different types of disadvantage, not necessarily correlating to each other and creating different spatial patterns (Hodge et al 2000; Martin et al 2000; Midgley et al 2003). These studies point out different manifestations of disadvantage in urban and rural environments. Midgley et al (2003) show e.g., that employment and housing availability are particularly urban issues, whereas employment quality and low income are forms of disadvantage related mostly to rural areas. The specifics of rural deprivation have been stated also in a New Zealand based study. Pearce et al (2008) found a strong relationship between constrained access to services and deprivation in rural areas, whereas in urban areas, accessibility constraints have been completely independent from deprivation.

Still, another theoretical stream conceptualises rural and urban disadvantage in terms of social exclusion resulting from the interplay of global and local forces in a specific territory. The concept of social exclusion has been found to be attractive for social science research due to its multidimensional and process-related nature. Being generally understood as missing or limited integration of specific population groups into important societal relations, social exclusion has been repeatedly conceptualised in rural studies as the malfunctioning of several integration processes: economic processes integrating individuals in market relations, administrative processes integrating individuals into political and state supportive networks, community processes and familial and friendship network processes (Shucksmith, Philip 2000; Commins 2004; Reimer 2004) A number of studies used this concept of social exclusion to uncover disadvantage related to rural areas. Various deficiencies have been found to increase social exclusion in rural areas: particularly accessibility of public services and their quality, including educational services, child care and social services have been described (Roscigno and Crowley 2001; Roscigno et al. 2006; Alston and Kent 2009; Shucksmith 2004; Sikora 2007); constrained 
access to public transport (Philip and Shucksmith 2003; Gray et al. 2006; Plazinic and Jovic 2014); missing or inadequate political representation (Philip and Shucksmith 2003). Local class conflicts concerning land use and the level of conservation, which have the potential to increase the property prices have been also found to complicate housing affordability and contribute to social exclusion for some groups of rural inhabitants (Philip and Shucksmith 2003). In general, the focus on social exclusion highlights the differential outcomes of rural living for different groups of residents. The dynamic transformations of rural areas always have winners and losers and can hardly be interpreted in a unidimensional manner.

The general results from these heterogeneous groups of studies can be summarised as follows: In most countries, rural areas experience slightly higher levels of poverty and deprivation, offering less favourable living conditions. In Europe, this gap is significantly more pronounced in eastern and southern European countries, whereas it is almost non-existent in some western states. Moreover, the problems related to the rural life are slightly differently structured than urban problems. Low quality labour and difficult accessibility to various opportunities, including public services, belong to the main rural difficulties. However, rural areas are highly diversified. Particularly, remote rural areas and rural areas in deindustrialised regions are prone to increased levels of disadvantage. On the other hand, deteriorated living conditions are not necessarily reflected in lower levels of subjective indicators like life satisfaction. On the contrary, rural living is of great value for many rural inhabitants, despite worse economic conditions. It is probable, that rural amenities resulting from lower population densities, lower pollution or lower criminality levels, outweigh positively the disadvantages of missing rural opportunities in the perceptions of the residents. In course of various transformations through which the countryside passes, some groups of rural inhabitants are at risk of becoming marginalized. Even economic strengthening and the influx of new inhabitants are not generally positive for all members of local communities. Particularly processes of land-use planning and zoning have been described as having the potential to exclude some local groups.

Despite large evidence on rural specifics of quality of life and forms of disadvantage, the issue of within-rural territorial differentiation in terms of quality of life has been sparsely investigated. The article contributes to the studies on rural living conditions by exploring various quality of life measures in different types of rural localities, focusing on the comparison of disadvantaged peripheral areas with other rural localities and cities. As shown in the above overview, studies on various aspects of rural quality of life and rural disadvantage have particularly focused on the following aspects: 1: Poverty and economic hardship, 2: Subjective well-being and satisfaction, 3: Opportunity deprivation and accessibility related difficulties. In the following parts of the article, I am addressing all these three aspects using my own designed survey. First, a territorial classification of rural areas according to area-level disadvantage indicators is performed. Second, urban-rural differences in QOL are analysed together with within-rural QOL differences. Third, the net-impact of the residential environment on QOL is assessed.

\section{Territorial classification of rural areas in Czechia according to disadvantage levels}

The first step of the analysis consisted of the delimitation of disadvantaged peripheral rural areas representing specific regions with accumulation of different forms of social disadvantage. The approach was based on the premise that the concept of disadvantage is multidimensional and that there are several spatial patterns of concentrated disadvantage ${ }^{2}$ (similar to Midgley et al 2003).

Generally, previous studies (Blažek, Csank 2007, Hampl 2007, Musil, Müller 2008) show that the socio-spatial differentiation processes of the recent and distant past have resulted in two types of economically disadvantaged regions in the Czech Republic. The first one, related to the postindustrial restructuring of the post-socialist transformation, concerns previously heavily industrialised regions affected by structural problems accompanied by the loss of high numbers of employment opportunities (Blažek, Csank 2007, Hampl 2007). Both cities and rural areas of

\footnotetext{
${ }^{2}$ For a more detailed account on the approach see (Bernard, Šimon 2017)
} 
the regions have been affected by the restructuring process. The dominant social problem of this type of territory is a high unemployment rate and the attendant risks of material deprivation and social exclusion. The second type of disadvantaged regions is rural territories which have experienced a long-term population decline as a result of polarisation processes between regional centres and their peripheries (Musil, Müller 2008, Bernard, Šimon 2017). This progressively led to a loss of functions of the territory in question, to selective migration and ageing. The postcommunist transformation of the last decades has not reversed this trend. The predominant part of thus affected territories is distinguished by low population densities, difficult access to certain services, low-skilled and low-paid jobs. Even if the post-communist transformation affected sociospatial processes differently in different countries, the classification of two different types of disadvantaged regions can be considered more general. In a similar sense, Pénzes (2013) states that, with a certain simplification, it is possible to speak of two types of disadvantaged or peripheral regions in Central Europe. Whereas the first type of periphery concerns previously economically prosperous areas that have encountered problems as a consequence of economic transformation, the second type concerns traditionally weak peripheral territories with a distinctly rural residential structure.

The area-level indicators used in this study have been selected to delineate these two types of disadvantaged regions. The first set contains variables used in a range of classical and more recent deprivation indices (Townsend 1987, Messer et al 2006) and point to the risk of labour market exclusion and exclusion from the educational process: unemployment level, the share of households dependent on housing allowances, the share of young people (aged 17-18) out of education, and the share of persons with elementary education.

The second set of variables indicates limited opportunity structures in terms of accessibility problems and a secondary labour market principally characterised by low wages, little chance of promotion and low educational returns (Thompson, Gray 1995; Harrison, Sum 1979; Kalleberg, Sorensen 1979): average monthly income from employment, share of residents in highly qualified occupations, overqualification indicated by the share of people with completed secondary education employed in occupations requiring usually a lower educational level and worsen spatial accessibility of a range of services. As most of the indicators are derived from census 2011 data, other information has also been related to 2011 to ensure coherence.

The both sets of indicators were proven to distinguish well between different types of Czech peripheries in a previous study (Bernard, Šimon 2017). Values of area-level variables were obtained for 1424 sub-regional units covering the whole Czech territory, used previously by Musil and Müller (2008) to delineate peripheral areas. They represent functional territorial units at the micro-regional level, albeit smaller than the regions of commuting. The advantage of these units lies in the fact that they represent small territories enough to sensitively capture the living conditions of households in the area and are not subject to extreme fluctuations due to a small number of people in individual municipalities. Urban localities have been defined as units whose largest community has more than 10,000 inhabitants (130 units).

The usability of both variable sets to indicate two separate types of disadvantaged rural regions was indicated by exploratory factor analysis which identified two independent factors, one defined predominantly by the first set and the other by the second set of variables. However, as I expected the both types of disadvantage to overlap partially in space and to be inter-correlated, I did not use scores of orthogonal factors for further analyses. Instead, I developed two resulting spatial dimensions of disadvantage using both sets of variables independently. The underlying variables have been standardized using the Z-score transformation and the values of the standardized variables have been summed ${ }^{3}$. I refer to the first resulting dimension "rural social exclusion" and to the second one "rural peripherality". Finally, to categorize the Czech countryside according to the two dimensions, both scales have been categorized into tercils. Table 1 summarizes the indicators used and the mean values in rural and urban territorial units. Figures 1 and 2 display the spatial patterns of both spatial dimensions of disadvantage.

\footnotetext{
${ }^{3}$ Variables within the both sets are highly inter-correlated and both resulting scales reach high internal consistency levels, with Cronbach's alpha 0.78 for the rural social exclusion dimension and 0.81 for the rural peripherality dimension.
} 
Tab 1. Indicators of territorial disadvantage. Source: author

\begin{tabular}{|l|l|l|}
\hline Indicators used in the dimension "rural social exclusion" & $\begin{array}{l}\text { Mean value } \\
\text { in rural units }\end{array}$ & $\begin{array}{l}\text { Mean value } \\
\text { in urban units }\end{array}$ \\
\hline Unemployment rate (Census 2011) & 0.11 & 0.10 \\
\hline Share of persons aged 17-18 out of education (Census 2011) & 0.06 & 0.06 \\
\hline $\begin{array}{l}\text { Share of persons with elementary education aged 25-50 } \\
\text { (Census 2011) }\end{array}$ & 0.08 & 0.08 \\
\hline $\begin{array}{l}\text { Share of households dependent on housing allowances } \\
\text { (Ministry of labour, 2011) }\end{array}$ & 0.02 & 0.04 \\
\hline $\begin{array}{l}\text { Indicators used in the dimension "rural peripherality" } \\
\text { Share of persons in highly qualified occupations ISCO 1 and 2 } \\
\text { (Census 2011) }\end{array}$ & 0.18 & 0.23 \\
\hline Overqualification rate (Census 2011) & 0.40 & 0.35 \\
\hline $\begin{array}{l}\text { Average monthly income as indicated by individual tax returns } \\
\text { (Ministry of Finance, 2011) }\end{array}$ & 22,515 CZK & 24,443 CZK \\
\hline Accessibility index & 946 & $\begin{array}{l}\text { Not } \\
\text { calculated }\end{array}$ \\
\hline Number of territorial units & $\mathbf{1 , 2 9 4}$ & $\mathbf{1 3 0}$ \\
\hline
\end{tabular}

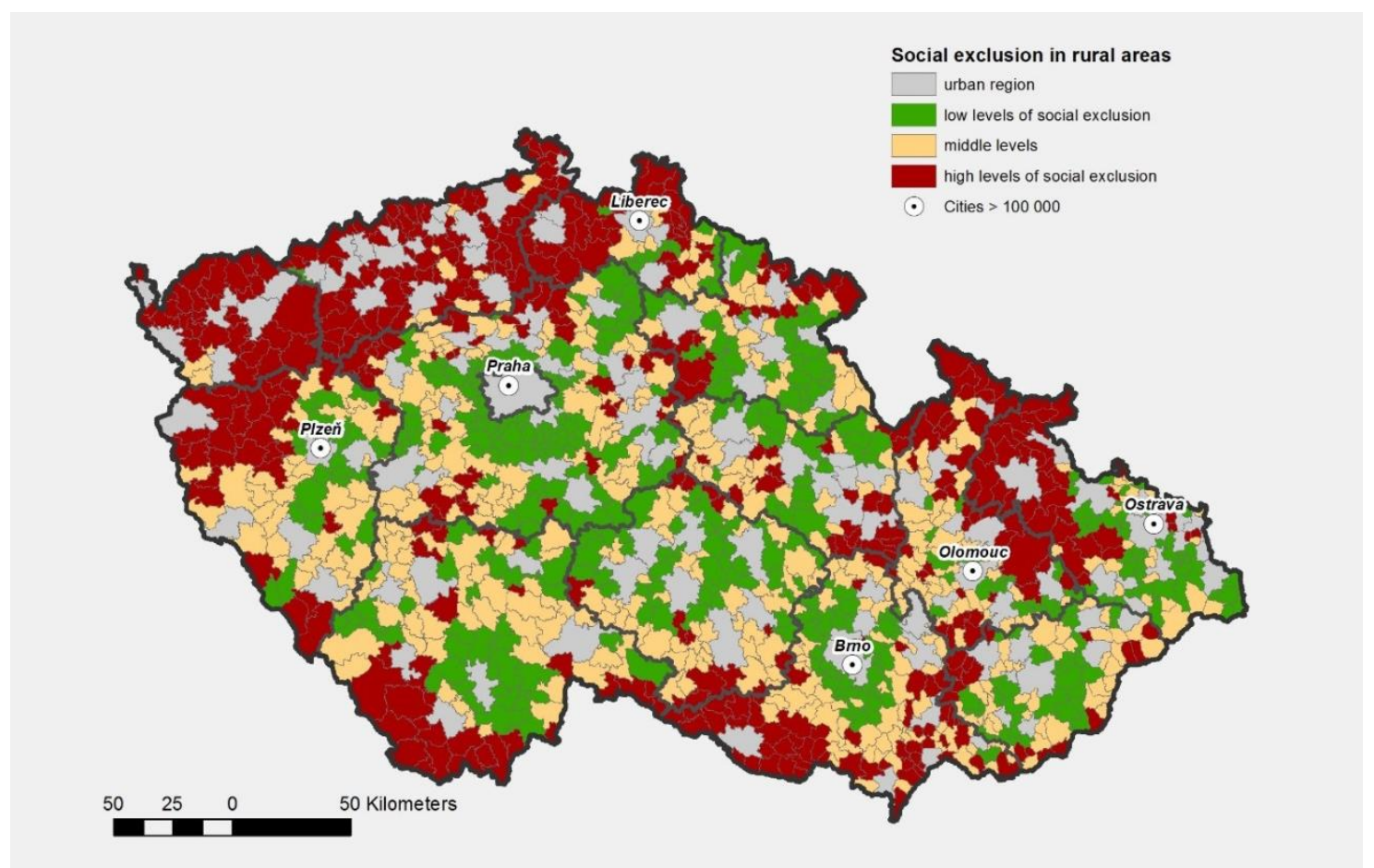

Fig 1. Social exclusion in rural areas. Source: own calculations

\footnotetext{
${ }^{4}$ Defined as the share of persons with complete secondary education employed in occupations where secondary education is not commonly required

${ }^{5}$ Accessibility index was calculated as a sum of sub-indices that reflect the travel accessibility of basic public services (different types of health services, secondary education), job opportunities and settlement centers (measured as the time required to overcome the specified distance by individual car transport. For this purpose, car accessibility was calculated from the core (largest) municipalities of all micro-regions to selected municipalities providing certain types of services or a specific number of job opportunities. For more details see Bernard, Šimon (2017).
} 


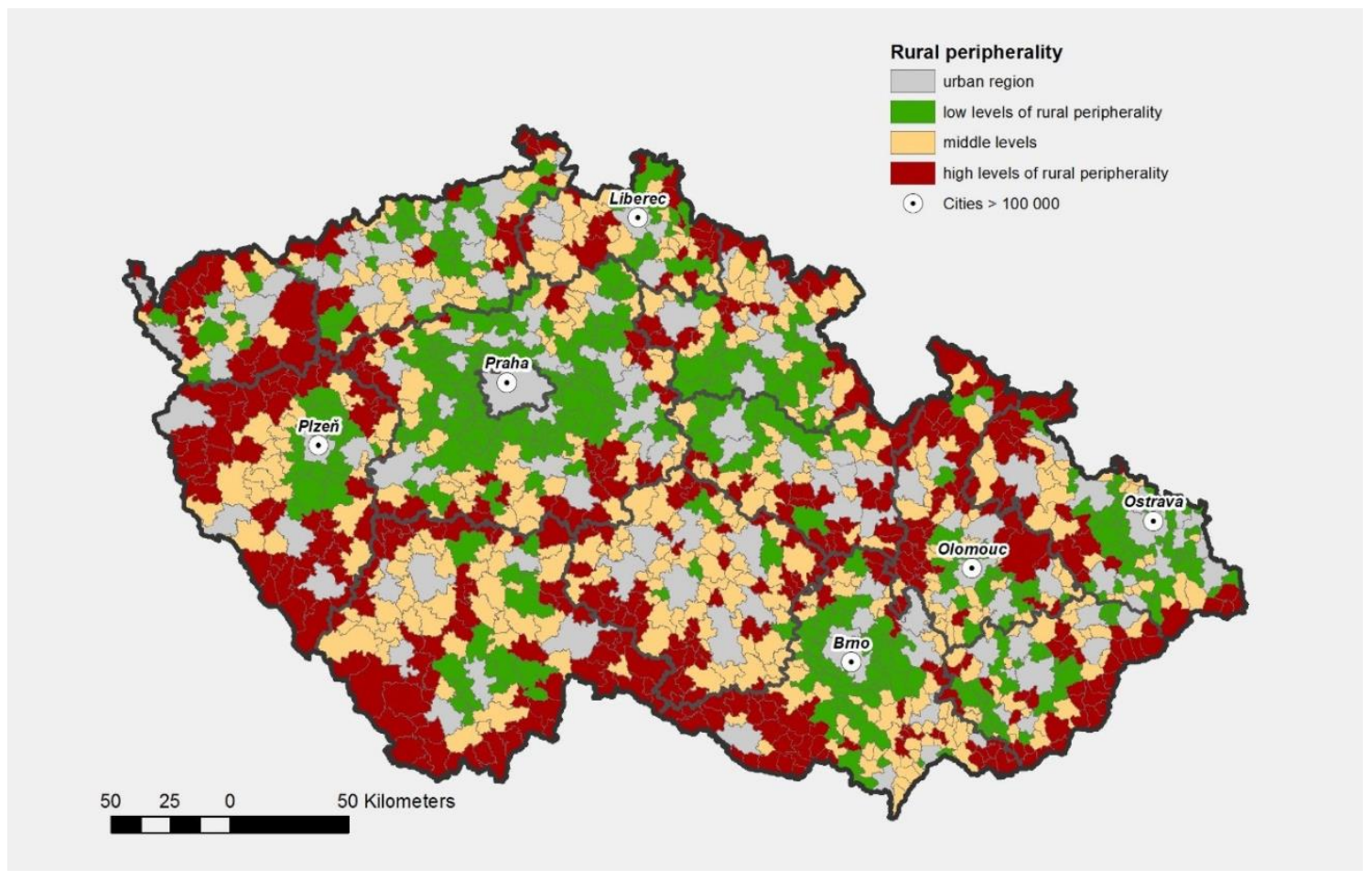

Fig 2. Rural peripherality. Source: own calculations

In 230 territorial units, both dimensions indicate low levels of disadvantage, in 216 units, both dimensions show increased disadvantage. Low disadvantage units concentrate particularly in the surroundings of the biggest Czech cities, whereas high disadvantage units in both dimensions concentrate in some border regions and in sparsely populated parts of regions resettled after the expulsion of the German population. The spatial and social characteristics of the disadvantaged regions have been described in detail elsewhere (Bernard, Šimon 2017). In this article, I am much more interested in how living in different types of rural regions impact on the resident's quality of life.

\section{Operationalisation of quality of life indicators and data description}

To investigate quality of life in different types of rural areas, survey data has been used. The survey, conducted in spring $2016^{6}$, was designed as part of a research project on social disadvantage in rural peripheries. For this purpose, a representative data set $(\mathrm{N}=2,466)$ has been collected, stratified according to four territorially defined strata. 1: urban regions $(\mathrm{N}=493)$, 2: prosperous rural areas $(\mathrm{N}=491), 3$ : average rural areas $(\mathrm{N}=511)$, 4: peripheral rural areas $(\mathrm{N}=971)$. Stratification of the data set was used to ensure a sufficient amount of respondents in different types of rural areas, for a meaningful statistical comparison. In individual strata, quota sampling was performed, taking into account sex, education, age, municipal size and NUTS III regions.

Poverty and economic hardship have been operationalised using the question how difficult it would be for a household to pay an unexpected expenditure of 9,600 CZK. This is a classic question used repeatedly as a part of subjective indicators of poverty and material deprivation, among others in the EU-SILC survey. Households indicating that they are not able to pay such an expenditure are considered to be endangered by poverty and living in economic hardship. The answers form a 4-point scale that has been reversed for the purpose of the analysis, so that 1 indicates highest difficulties and 4 the absence of difficulties, i.e., ease of paying the amount.

Subjective well-being and satisfaction have been operationalized using the community satisfaction index. Community satisfaction has been repeatedly used as an indicator of

\footnotetext{
${ }^{6}$ The data have been collected in form of a PAPI survey by the Centre for Public Opinion research (CVVM) operating as part of the Institute of Sociology of the Czech Academy of Sciences.
} 
community's quality of life and the quality of its social and natural environment (Theodori 2001; Potter and Cantarero 2006; Athiyaman and Walzer 2008; Sirgy et al. 2008; Bernard 2014). The indicator is based on three questions: (1) 'How much would you agree or disagree with the statement that the place where you live is a good place to live? (2) 'How satisfied or dissatisfied are you personally with the conditions in your place of residence? Think about a variety of aspects of life. (3) 'Try to assess the place where you live in general. In your opinion, how attractive is this place compared to other places?' The summative scale of these variables exhibits solid reliability (Cronbach's alpha $=0.88$ ), and was used as the indicator of general community satisfaction.

Three questions have been used to operationalise opportunity deprivation and accessibility related difficulties. Respondents have been asked to assess, how difficult it would be for them personally or for members of their households to (1) find an appropriate job in case of unemployment, (2) visit a general practitioner if necessary, (3) buy food and everyday necessities in sufficient extent and quality. All three variables consist of 5-point scales, with 1 indicating highest difficulties and 5 the absence of difficulties. These three variables have been analysed separately.

Besides place of residence categorised into urban areas and different types of rural localities, the following variables have been used as control independent factors in models explaining the different aspects of quality of life: sex, education, age, household composition, municipal size. Table 2 provides descriptive statistics for the variables used in the analyses.

Tab 2. Descriptive statistics. Source: Survey social disadvantage in peripheral rural areas, 2016

\begin{tabular}{|lc|}
\hline Outcomes & Mean \\
\hline Easy paying unexpected expenditure (4-point scale: 1 high difficulties - 4 easy) & 2.76 \\
Community satisfaction (19 point scale: 1 low satisfaction - 19 high satisfaction) & 13.87 \\
Easy finding a job (5-point scale: 1 high difficulties - 5 easy) & 2.46 \\
Easy visiting a GP (5-point scale: 1 high difficulties - 5 easy) & 3.88 \\
Easy shopping (5-point scale: 1 high difficulties - 5 easy) & 4.03 \\
\hline Control variables & Proportion \\
SEX & \\
Female & 0.52 \\
Male & 0.48 \\
AGE & \\
Age 21-29 & 0.16 \\
Age 30-59 & 0.56 \\
Age 60+ & 0.28 \\
EDUCATION & \\
Tertiary education & 0.11 \\
Complete secondary education & 0.30 \\
Basic education and secondary education without final exam & 0.59 \\
HOUSEHOLD COMPOSITION & \\
No children under 15 & 0.76 \\
At least one child under 15 & 0.24 \\
MUNICIPAL SIZE & \\
Municipal size < 500 & 0.14 \\
Municipal size 500-3 000 & 0.41 \\
Municipal size more than 3 000 & 0.45 \\
\hline
\end{tabular}




\section{Types of regions}

SOCIAL EXCLUSION

urban region

rural - low levels of social exclusion

rural - average levels of social exclusion

rural - high levels of social exclusion

RURAL PERIPHERALITY

urban region

rural - low levels of rural peripherality

0.26

rural - average levels of rural peripherality

0.28

rural - high levels of rural peripherality

0.25

Number of observations

2,466

\section{Results of the analysis}

In the first step, differences in the values of individual outcome variables between urban and rural regions were calculated (table 3 ).

Tab 3. Urban-rural differences in selected QOL indicators. Source: Survey social disadvantage in peripheral rural areas, 2016, number of cases in the analyses: $N=2306, N=2396, N=2132, N=2427, N=2408$

\begin{tabular}{|l|c|c|c|}
\hline & Rural mean & Urban mean & sig. \\
\hline Easy paying unexpected expenditure & 2.78 & 2.74 & 0.352 \\
\hline Community satisfaction & 14.11 & 13.69 & 0.008 \\
\hline Easy finding a job & 2.33 & 2.56 & 0.000 \\
\hline Easy visiting a GP & 3.65 & 4.06 & 0.000 \\
\hline Easy shopping & 3.84 & 4.18 & 0.000 \\
\hline
\end{tabular}

The results show no difference between rural and urban areas in terms of the ability to pay an unexpected expenditure, which indicates approximately the same level of poverty and economic hardship. Community satisfaction levels are slightly higher in rural areas compared to cities. On the contrary, rural residents express difficulties finding jobs and accessing basic services more often than their urban counterparts, which indicate increased levels of opportunity deprivation in rural areas. The differences, albeit statistically significant, are rather modest. E.g. the shares of people expressing no difficulties at all with finding a job, visiting a GP or shopping reach in rural areas $7 \%, 31 \%$ and $38 \%$, whereas in urban regions these shares are slightly higher, reaching $10 \%, 48 \%$ and $52 \%$.

In the second step, the classification of rural areas according to the two dimensions of disadvantage described above has been used to examine the differentiation of QOL within rural regions.

Tab 4. Selected QOL indicators in different rural areas according to the dimension rural social exclusion. Source: Survey social disadvantage in peripheral rural areas, 2016. Number of cases in the analyses: $N=2306, N=2396, N=2132$, $N=2427, N=2408$

\begin{tabular}{|l|c|c|c|c|}
\hline \multirow{2}{*}{} & \multicolumn{4}{|c|}{ Social exclusion in rural areas } \\
\cline { 2 - 5 } & low levels & medium levels & high levels & sig. \\
\hline Easy paying unexpected expenditure & 2.93 & 2.80 & 2.59 & 0.000 \\
\hline Community satisfaction & 14.96 & 13.99 & 13.19 & 0.000 \\
\hline Easy finding a job & 2.44 & 2.39 & 2.13 & 0.000 \\
\hline Easy visiting a GP & 3.70 & 3.75 & 3.47 & 0.000 \\
\hline Easy shopping & 3.90 & 3.85 & 3.76 & 0.113 \\
\hline
\end{tabular}


Tab 5. Selected QOL indicators in different rural areas according to the dimension rural peripherality. Source: Survey social disadvantage in peripheral rural areas, 2016. Number of cases in the analyses: $N=2306, N=2396$, $N=2132, N=2427, N=2408$

\begin{tabular}{|l|r|r|r|c|}
\hline \multirow{2}{*}{} & \multicolumn{4}{|c|}{ Rural peripherality } \\
\cline { 2 - 5 } & low levels & medium levels & high levels & sig. \\
\hline Easy paying unexpected expenditure & 2.79 & 2.79 & 2.78 & 0.989 \\
\hline Community satisfaction & 14.62 & 13.82 & 13.40 & 0.000 \\
\hline Easy finding a job & 2.43 & 2.27 & 2.21 & 0.008 \\
\hline Easy visiting a GP & 3.78 & 3.59 & 3.44 & 0.000 \\
\hline Easy shopping & 3.93 & 3.86 & 3.59 & 0.000 \\
\hline
\end{tabular}

Both dimensions of disadvantage proved highly valid in determining the QOL indicators. The assumption that levels of QOL differ between rural areas with low and high levels of disadvantage is fully proved. Moreover, the results show that the two dimensions of disadvantage impact different aspects of QOL. It proved for both dimensions of disadvantage, that community satisfaction in disadvantaged rural areas is significantly lower than in other rural localities. Despite in average higher community satisfaction in rural areas compared to cities, rural areas suffering increased levels of disadvantage experience even lower community satisfaction than urban regions. As expected, in rural areas suffering increased levels of social exclusion, more residents claim having difficulties paying unexpected expenditures and the majority of inhabitants expect difficulties in searching a job. Also visiting a general practitioner is related to higher difficulties in rural areas with increased levels of social exclusion. In rural areas with high levels of peripherality, i.e., areas characterised by accessibility problems, lower income and lower education, poverty and economic hardship is not the major problem. Apparently, these regions do not experience increased concentrations of households living on the margins of poverty and material deprivation. The major obstacle, the residents of these areas face, is much more opportunity deprivation. Their inhabitants experience higher difficulties in visiting a GP or shopping than in any other type of region.

For a clearer comparison, I displayed the Z-transformed values of the outcome variables in a radar chart, enabling such a direct comparison of several types of regions - urban, rural as a whole, rural periphery and rural with increased level of social exclusion.

The chart displays once again the comparison between urban and rural regions and the two disadvantaged types of rural regions. ${ }^{7}$ Urban regions are the clear winner in all three opportunity deprivation indicators. Living in urban regions reduces difficulties in finding jobs, visiting GP and shopping. At the same time, it shows that these urban-related advantages do not transform in higher community satisfaction and are not reflected in increased levels of poverty and economic hardship in rural areas in general. Disadvantaged rural areas experience lower QOL levels in almost all indicators. For residents in rural territories with increased social exclusion, poverty and problems with finding a job are most painful, whereas for inhabitants of rural peripheries problems with shopping and accessing other important services are a big difficulty.

\footnotetext{
7 The graph enables the summative comparison of strengths and weaknesses of different types of regions well. However, as the values have been standardised, the individual axes cannot be directly compared to each other. Questions like: is visiting a GP in urban areas related to more or less obstacles than shopping, cannot be answered from the graph.
} 


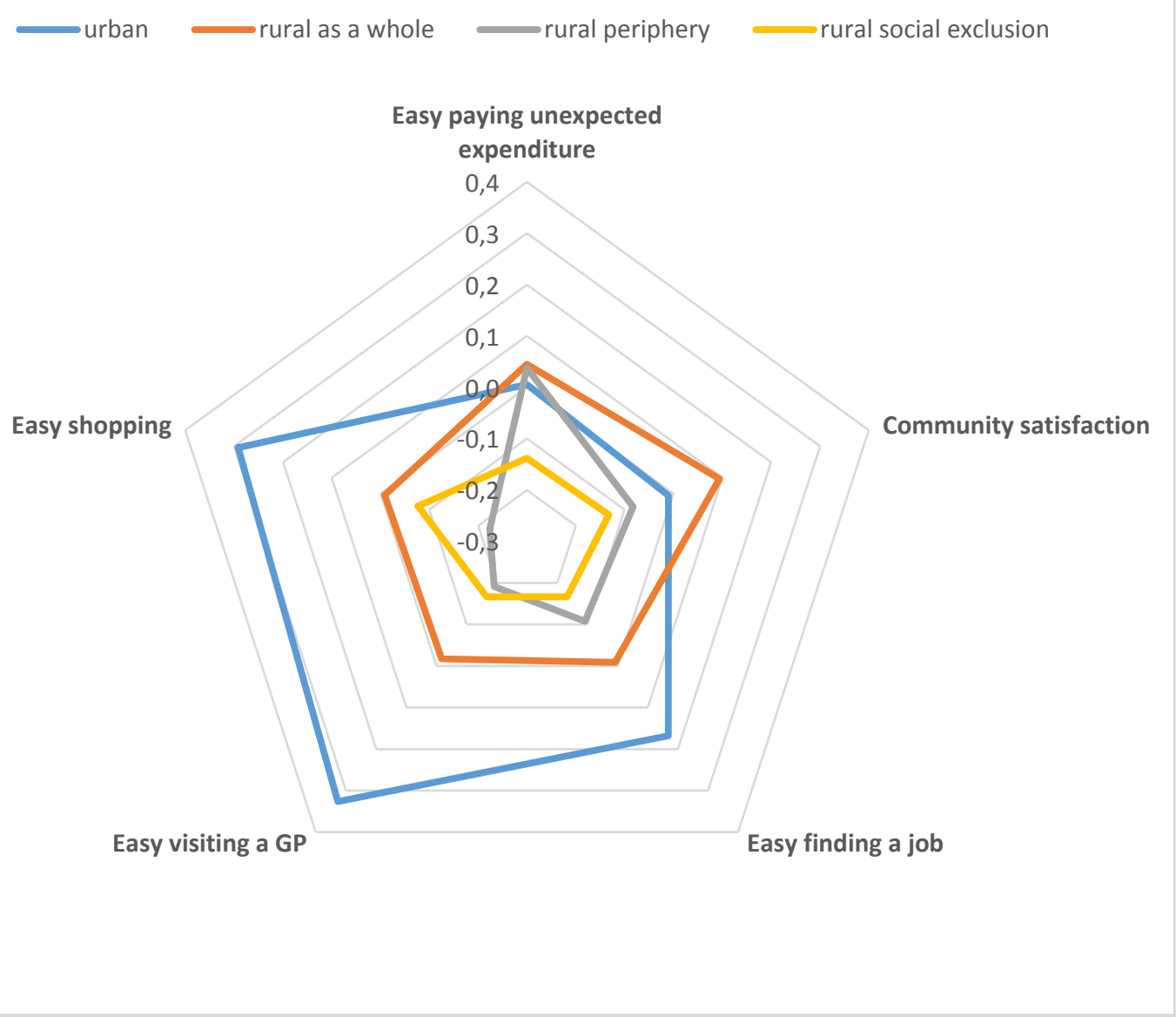

Fig 3. Comparison of standardized QOL indicators in four types of regions. Source: Survey social disadvantage in peripheral rural areas, 2016

So far, the findings have not exceeded a descriptive level. In the subsequent analysis, I went one step further, asking what the differences in QOL between different territories result from. There are two basic explanations of such differences. According to the first one, the territorial differences are reflections of the population composition. In this explanation, it is not the territorial context as such that impacts on quality of life. The real drivers of quality of life are much more properties, characters and capitals belonging to individual people. According to this explanation, differences found e.g., between rural and urban regions in terms of difficulties in finding an appropriate job would be particularly reflections of the educational level and aspirations of urban and rural populations. The second explanation is a contextual one. It takes the notion of the residential context as an important driver of individual fortunes seriously. In a contextual manner, differences in quality of life between different territories can be explained by the characteristics of the residential environment that offers unequal access to various opportunities and determines the capabilities individual residents have for reaching their preferred goals. Both explanations are not mutually exclusive and in many cases, both of them explain part of the reality.

I tested, whether the effect of territorial differences persist even after inclusion of individual-level control variables. If the whole difference in QOL or the dominant part of it can be explained by individual level variables, it would be a strong argument for the compositional explanation. If territorial differences remain statistically significant and factually relevant after controlling for the most important individual controls, the validity of the contextual explanation would be strengthened. Sex, educational level, age and the presence of children in the household have been selected as individual-level controls. Moreover, municipal size was included as a control variable to test, whether the differences between different types of regions are not mere reflections of their settlement structure. Binary logit regressions for all five outcome variables have been performed. Outcomes have been dichotomised to distinguish between respondents who 
state perceiving no significant difficulties in paying unexpected expenditures, finding a job, visiting a GP, or shopping, and respondents who perceive some or big difficulties. Community satisfaction variable was dichotomised to distinguish between respondents with the highest satisfaction (25\% of respondents) and others. Table 6 specifies the dichotomisation of individual outcomes. Thus, I tested, whether living in a specific type of region exhibits a direct impact on the chance of perceiving/not perceiving difficulties and on expressing high community satisfaction.

Tab 6. Dichotomisation of outcome variables for the purpose of binary logit models.

\begin{tabular}{|l|l|l|}
\hline & \multicolumn{2}{|c|}{ Dichotomisation } \\
\hline $\begin{array}{l}\text { Easy paying unexpected } \\
\text { expenditure }\end{array}$ & \multicolumn{1}{|c|}{\begin{tabular}{c}
\multicolumn{1}{c|}{ Values 1, 2 (can hardly pay, } \\
can not pay at all)
\end{tabular}} & $\begin{array}{l}\text { Values 3, 4 (can surely pay, } \\
\text { can probably pay) }\end{array}$ \\
\hline High community satisfaction & $\begin{array}{l}\text { Values 1-16 (75\% } \\
\text { respondents with average } \\
\text { and low satisfaction) }\end{array}$ & $\begin{array}{l}\text { Values 17-19 (25\% } \\
\text { respondents with highest } \\
\text { satisfaction) }\end{array}$ \\
\hline Easy finding a job & Values 1-3 (difficult) & Values 4-5 (easy) \\
\hline Easy visiting a GP & Values 1-3 (difficult) & Values 4-5 (easy) \\
\hline Easy shopping & Values 1-3 (difficult) & Values 4-5 (easy) \\
\hline
\end{tabular}

For each variable, two models have been elaborated, the first one with the territorial dimension rural social exclusion and the second one with rural periphery. Due to extent, I will not present the whole models. Instead, in Figures 4 and 5, estimated marginal probabilities of dichotomised outcome categories for one typical person are displayed: a women, aged 30-50, with basic or secondary education without final exam, living in a household without children under 15 , in a municipality with more than 3,000 inhabitants. All individual-level controls have been fixed at these values ${ }^{8}$.

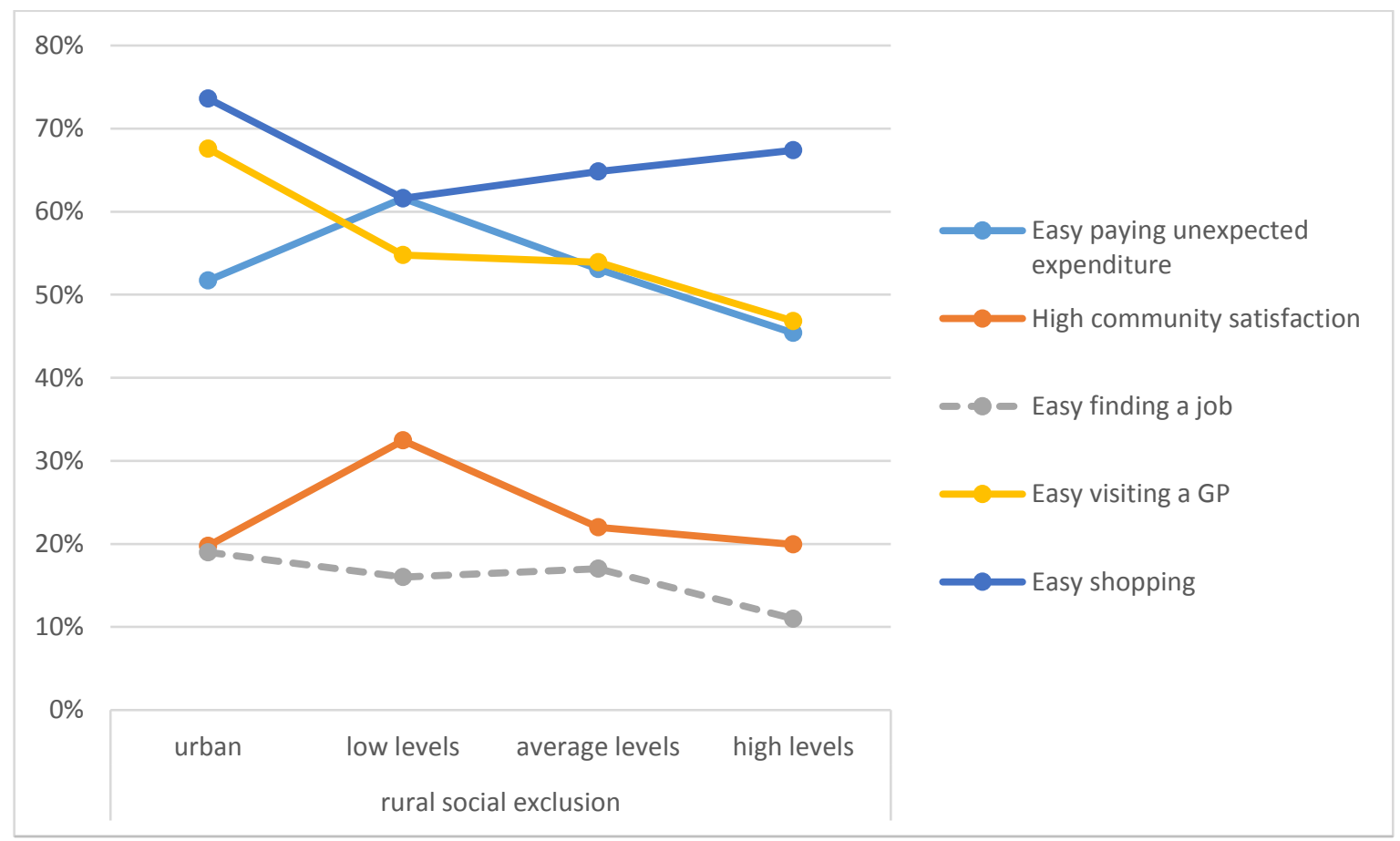

Fig 4. Estimated marginal probabilities for 5 dichotomised outcome variables using the territorial dimension rural social exclusion, binary logit models.

Note: Control variables fixed at values: woman, aged 30-60, basic or secondary education without final exam, living in a household without children under 15 , municipality with more than 3000 inhabitants. $N=2289, N=2379, N=2119$, $\mathrm{N}=2410, \mathrm{~N}=2391$. Dashed lines represent non-significant effect of the territorial classification at the significance level of 0.05 .

8 These values represent the most frequent categories in the sample. Complete models and estimated marginal probabilities for other persons are available from the author. 
The effect of control variables can be briefly summarised as follows: Age is very important in determining community satisfaction. Older people are more satisfied with their local community. On the other hand, older residents face higher obstacles in accessing a GP. Education is the key factor determining difficulties paying an unexpected expenditure, finding a job and even experiencing obstacles in accessing GP and shopping. More educated people report less frequently having significant obstacles than others. Households with children more often face difficulties paying unexpected expenditures and shopping. The same is true for women. Interestingly, the net effect of municipal size is not significant in the analyses, if territorial classification is included. It is not primarily the municipal size, but rather the territorial position what determines quality of life.

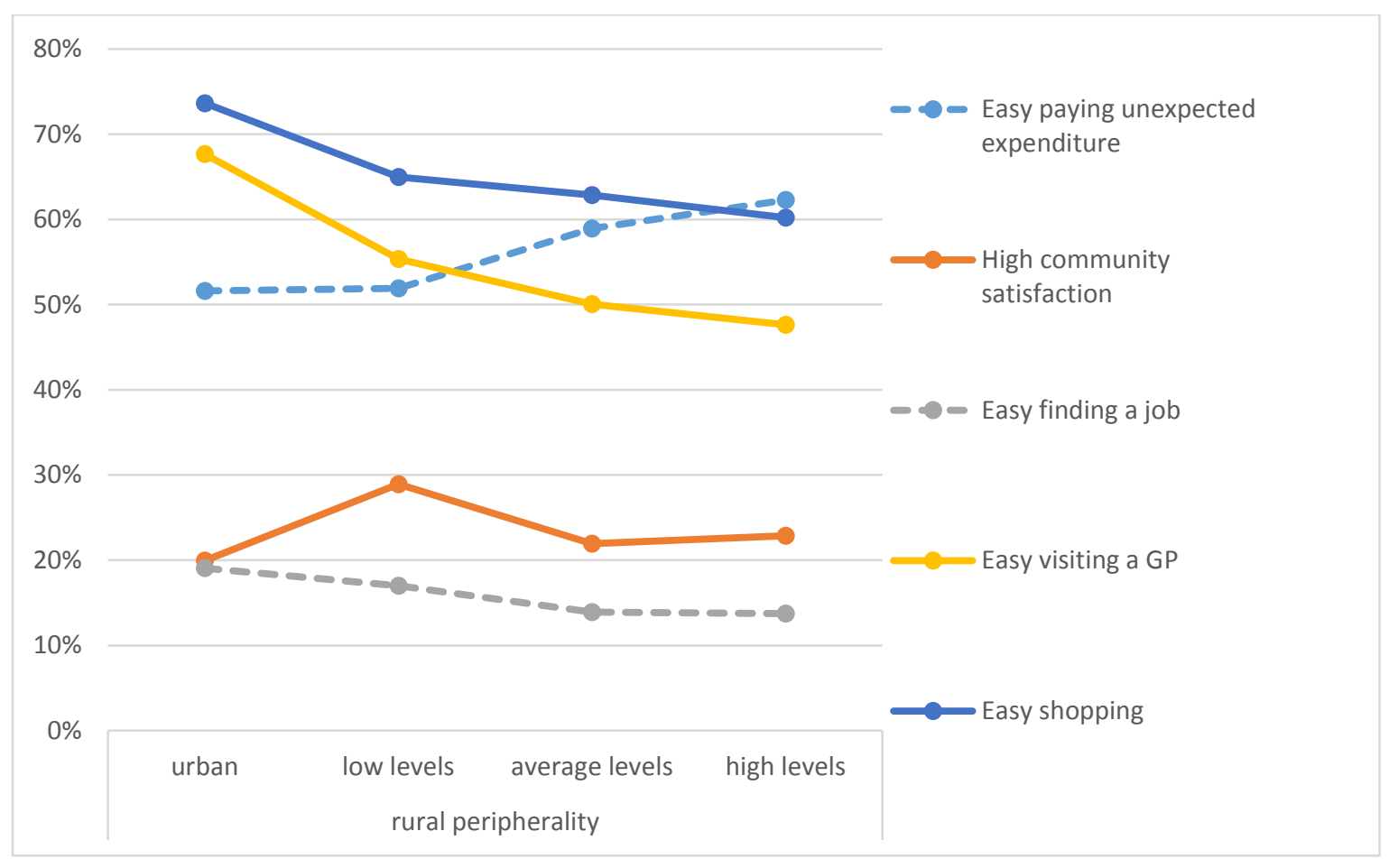

Fig 5. Estimated marginal probabilities for 5 dichotomised outcome variables using the territorial dimension rural peripherality, binary logit models.

Note: Control variables fixed at values: woman, aged 30-60, basic or secondary education without final exam, living in a household without children under 15 , municipality with more than 3000 inhabitants. $N=2289, N=2379, N=2119$, $\mathrm{N}=2410, \mathrm{~N}=2391$. Dashed lines represent non-significant effect of the territorial classification at the significance level of 0.05 .

In the dimension rural social exclusion, four out of five territorial effects proved significant after inclusion of individual level controls in the models. In the dimension rural peripherality, three out of five effects remained significant. Moreover, all the significant effects work in the same direction as the previous descriptive analysis. Living in urban regions is related to the lowest level of difficulties with visiting a GP and shopping. On the other hand, community satisfaction is significantly higher than elsewhere, particularly in the least disadvantaged rural regions and decreases rapidly with increasing territorial disadvantage. Especially, negative effects on community satisfaction have living in rural regions with concentrated social exclusion. Also, poverty issues represented here by difficulties paying unexpected expenditures are territorially affected. Differentiation of rural areas according to the social exclusion dimension separates regions with the lowest problems from regions where poverty issues are a significant problem. As expected, the rural peripherality dimension is not significant for poverty issues. The same is true for difficulties finding a job?

\footnotetext{
${ }^{9}$ To enhance the validity of the result, I also conducted ordinal regression analysis with the underlying, not dichotomized outcome variables. The results are essentially the same. Details of the analysis can be obtained from the author.
} 


\section{Conclusion}

For this paper, three innovative elements in the study of rural quality of life have been set. (1) To go beyond the urban-rural dichotomy of quality of life and to introduce a meaningful rural territorial differentiation that affects quality of life. The analysis did not confirm the previous findings about missing rural-urban differences in quality of life in Czechia. On the contrary, it showed significant, albeit rather modest differences in community satisfaction in favor of rural communities and higher constraints in searching for jobs, shopping and visiting a GP in rural areas compared to cities. A situation that can be interpreted as increased probability of opportunity deprivation in the countryside. On the other hand, the analysis also confirmed that for three out of five indices, internal within-rural differences indeed are higher than the difference between urban and rural areas. This holds true for community satisfaction, the poverty indicator and the level of difficulties with finding a job. For all three indices, the proposed classification of the countryside into areas with high and low levels of disadvantage proved to be a valid instrument for identifying territorial hotspots of decreased rural quality of life. Furthermore, I also demonstrated, that the territorial differences in quality of life have a rather limited extent. Neither living in rural areas, nor in cities, but even neither in rural areas with high disadvantage concentrations should be understood as the main factor determining quality of life. The territorial classifications used in the regression models have a weak, albeit in most cases statistically significant explanative power. Most disadvantaged rural areas in Czechia are thus not to be understood as highly deprived places. They can rather be described as localities, whose inhabitants face slightly more obstacles in everyday life than other residents.

(2) I demonstrated furthermore the usefulness of a multidimensional territorial countryside differentiation. Instead of one core dimension of concentrated disadvantage, two dimensions have been introduced. Whereas areas with increased social exclusion are negatively affected particularly by limited availability of jobs, remote rural peripheries suffer predominantly from opportunity deprivation in terms of increased obstacles in accessing services. The largest territorial concentration of rural areas with increased social exclusion is located in deindustrialized regions at the north-western border. Their problems are not rurality specific, but rather affect the whole regions, including its cities. On the other hand, typical rural peripheries are located in relatively long distances from regional centers and in sparsely populated areas. Remoteness, transport difficulties and limited offer of services due to low population densities are the main drivers of the obstacles their inhabitants are exposed to. Residents of the both disadvantaged types of rural areas evaluate their residential environment relatively more critically, thus expressing decreased levels of community satisfaction. On the contrary, the highest community satisfaction is to be found in more affluent and well accessible rural communities.

(3) I have been able to prove that the relation between the residential environment in terms of different types of rural areas and the quality of life measures is not fully mediated by individuallevel controls. Better and/or worse evaluation of living conditions are not merely results of compositional effects reflecting specific social structures of the rural population. The effects of the residential environment remain significant after controlling for individual-level variables. It should be stated however, that even after controlling for individual-level variables, a causal influence of the residential context is not completely guaranteed. A fundamental difficulty is the problem of potential endogeneity of residential context in regressive models, which may ensue from reversal causality and omitted variables. Both of these complications are caused by systematic spatial selection processes. Place of residence is not randomly assigned, but depends on individual choices. In case of reversal causality, a reverse mechanism may apply, in which persons with a specific feature (e.g., living in poverty) select residence in different localities than others. The bias resulting from the omitted variables then consists of the fact that the correlation between characteristics of residential context and the dependent variable may ensue from a dependency of both of these variables on another, unmeasured variable. The proof of the causal mechanism would thus require further investigation, preferably using panel data.

I mentioned above that a similar typology of disadvantaged regions was proposed by Pénzes (2013) for other post-communist Central European countries that also have experienced a profound socio-economic transformation since the 1990s. However, the Czech countryside also 
differs in some ways from the situation in other Central European rural areas. It has been repeatedly described that in course of the societal transformation problems of agricultural and industrial job loss, unemployment and high levels of agricultural poverty emerged in some central and eastern European countries. In remote rural regions poverty, unemployment, and deprivation of opportunities accumulated. (Brown, Schafft 2003, Bock et al 2014, Swain 2016).

The post-communist rural transformation in the Czech Republic was partly different. It resulted in the existence of large agricultural holdings, very low numbers of small family farms, and a fast decline of the importance of agriculture for providing jobs in the countryside. Agricultural restructuring has not resulted in a significant increase of unemployment or the rise of agricultural poverty (Šimon, Bernard 2016). A high level of rural industrialization and a dense network of small and medium-sized towns in most regions, allowing daily commuting from a large part of rural settlements, made it possible to overcome the transformation relatively smoothly. Another important point in rural disadvantage in some Central European countries is related to the ethnic exclusion of the Roma and the related social problems (Růžička 2012, Swain 2016). Unlike in other Central and Eastern European countries, the Roma minority in the Czech Republic are mainly concentrated in cities and not very present in the countryside. Last but not least, the specifics of the Czech countryside is result of recent population deconcentration trends. As Swain (2016) summarizes, delayed suburbanisation appeared in many of the central European countries at the turn of the millennium, but in the Czech Republic, the majority of rural areas have been gaining new population through out-migration from cities in the last two decades. Population shrinkage can be observed just in a small minority of rural areas. Vicious circles of economic and demographic periferization, typical of a large part of the countryside of the former East Germany (Fischer-Tahir 2013), are absent in the Czech Republic. Considering these specifics, it can be assumed that the structure of social disadvantage and its spatial patterns in other Central and Eastern European countries will look somewhat different.

Nevertheless, the article also aims to offer new impulses for the study of inequalities resulting from the residential environment at a more general level. Most research of this kind so far has focused on living conditions in deprived urban neighborhoods. Increased poverty, high criminality and ethnic segregation have been repeatedly found to exhibit negative effects on residents. Much less attention has been paid to disadvantaged rural areas, partly because in rural areas, such high concentrations of disadvantage as in rural neighborhoods have been rarely found. I argue however that this neglect overlooks problems typical of rural populations, particularly the issue of opportunity deprivation in difficult accessible areas. One of the reasons is that the mainstream international research focuses on highly urbanized western European and U.S. societies in which urban poverty and social problems represent most pressing societal issues. However, in other parts of the world, e.g., in eastern Europe, deprivation issues are much more rurality focused (Shucksmith et al 2009). A convenient explanatory approach for the findings is the geography of opportunity approach that assumes that the spatial context in which people reside offers a diverse access to the opportunities that they can use to achieve their goals. Even in societies with a high degree of urbanization and relatively easy accessibility to cities from rural areas, housing in a rural environment is often associated with higher individual mobility demands than the urban environment and, particularly in more remote rural sites and in sparsely populated regions, increased barriers in accessing opportunities of different kinds can be found, which impacts the quality of life, particularly for less mobile population groups.

Last but not least, the findings represent a critical voice against recent statements of Czech public authorities about dilapidating quality of life in the smallest Czech rural municipalities and their depopulation, arguing that "for rural inhabitants, reasons for leaving to larger cities are primarily job search problems or a significantly greater risk of poverty" (Ministry of agriculture 2016). My findings offer a very limited empirical support for such a statement. Firstly, it is not primarily community size that determines the quality of life in a place. Much more, the location of the community in areas with increased levels of disadvantage is important. Even very small communities with well accessibility into economically viable cities and located outside of deindustrialized regions, experience on the contrary highest levels of satisfaction and outperform towns and cities in some aspects of quality of life. Secondly, poverty and job search problems are not the specific rural problem in Czechia. In most rural communities, poverty problems are not 
more concentrated than in cities. Accessibility to services, and everyday obstacles in achieving different sources of welfare, be it jobs, shops, GPs, and other institutions, represent a more pressing issue.

\section{Acknowledgment}

This work was supported by the Czech Science Foundation, GAČR, Grant No. 15-10602S.

\section{Academic references}

[1] Alston, M. \& Kent, J. (2009). Generation X-pendable The social exclusion of rural and remote young people. Journal of Sociology, 45(1), 89-107. DOI: 10.1177/1440783308099988.

[2] Athiyaman, A. \& Walzer, N. (2008). Strategies to Enhance and Maintain Quality of Life: The Case of Nonmetropolitan Illinois. Journal of Rural and Community Development 3(1), 41-59.

[3] Bernard, J. (2015). Community satisfaction in Czech rural communities: A multilevel model. Sociologia Ruralis, 55(2), 205-226. DOI: 10.1111/soru.12060.

[4] Bernard, J. \& Šimon, M. (2017). Vnitřní periferie v Česku: Multidimenzionalita sociálního vyloučení ve venkovských oblastech. Sociologický časopis 53(1), 3-28.

[5] Bernard, J., Decker, A., Mikešová, R. \& Vojtíšková, K. (2016). Living and Dealing with Limited Opportunities: Social Disadvantage and Coping Strategies in Rural Peripheries. Sociální studia/Social Studies, 13(2), not paged.

[6] Berry, B. J. \& Okulicz-Kozaryn, A. (2011). An urban-rural happiness gradient. Urban geography, 32(6), 871-883. DOI: 10.2747/0272-3638.32.6.871.

[7] Bock, B., Kovacs, K. \& Shucksmith, M. (2014). Changing social characteristics, patterns of inequality and exclusion. In Copus, A. K. \& de Lima, P., eds., Territorial Cohesion in Rural Europe: The Relational Turn in Rural Development (pp. 193-211). Abingdon: Routledge.

[8] Brown, D. L. \& Schafft, K. A. (2003). Social Exclusion in Rural Areas of Central and Eastern Europe. Eastern European Countryside 9, 27-44.

[9] Commins, P. (2004). Poverty and social exclusion in rural areas: characteristics, processes and research issues. Sociologia Ruralis, 44(1), 60-75. DOI: 10.1111/j.14679523.2004.00262.x.

[10] Cotter, D. A. (2002). Poor people in poor places: Local opportunity structures and household poverty. Rural Sociology, 67(4), 534-555. DOI: 10.1111/j.1549-0831.2002.tb00118.x.

[11] Dietz, R. D. (2002). The estimation of neighborhood effects in the social sciences: An interdisciplinary approach. Social Science Research, 31(4), 539-575. DOI: 10.1016/S0049-089X(02)00005-4.

[12] Fischer-Tahir, A. \& Naumann, M., eds. (2013). Peripheralization. The Making of Spatial Dependencies and Social Injustice. Wiesbaden: Springer VS.

[13] Fisher, M. (2005). On the Empirical Finding of a Higher Risk of Poverty in Rural Areas: Is Rural Residence Endogenous to Poverty? Journal of Agricultural and Resource Economics 30(2), 185-199.

[14] Gray, D., Shaw, J. \& Farrington, J. (2006). Community transport, social capital and social exclusion in rural areas. Area, 38(1), 89-98. DOI: 10.1111/j.1475-4762.2006.00662.x.

[15] Hodge, I., Dunn, J., Monk, S. \& Kiddle, C. (2000). An Exploration of 'Bundles' as Indicators of Rural Disadvantage. Environment and Planning $A, 32(10)$, 1869-1887. DOI: $10.1068 / a 32196$. 
[16] Chromý, P., Jančák, V., Marada, M. \& Havlíček, T. (2011). Venkov-žitý prostor: regionální diferenciace percepce venkova představiteli venkovských obcí v Česku. Geografie, 116(1), 23-45.

[17] Lichter, D. T. \& Johnson, K. M. (2007). The changing spatial concentration of America's rural poor population. Rural Sociology, 72(3), 331-358. DOI: 10.1526/003601107781799290.

[18] Martin, D., Brigham, P., Roderick, P., Barnett, S. \& Diamond, I. (2000). The (mis) representation of rural deprivation. Environment and Planning A, 32(4), 735-751. DOI: $10.1068 / a 32130$.

[19] Midgley, J., Hodge, I. \& Monk, S. (2003). Patterns and concentrations of disadvantage in England: A rural-urban perspective. Urban Studies, 40(8), 1427-1454. DOI: 10.1080/0042098032000094379.

[20] Migheli, M. (2017). Size of Town, Level of Education and Life Satisfaction in Western Europe. Tijdschrift voor economische en sociale geografie, 108(2), 190-204. DOI: 10.1111/tesg.12205.

[21] Musil, J., Müller, J. (2008). Vnitřní periferie v České republice jako mechanismus sociální exkluze. Sociologický časopis/Czech Sociological Review 44(2): 321-348.

[22] Ouředníček, M., Špačková, P. \& Feřtrová, M. (2011). Změny sociálního prostředí a kvality života v depopulačních regionech České republiky. Sociologický časopis 47(4), 777-803.

[23] Pearce, J., Witten, K., Hiscock, R. \& Blakely, T. (2008). Regional and urban-rural variations in the association of neighbourhood deprivation with community resource access: a national study. Environment and Planning A, 40(10), 2469-2489. DOI: 10.1068/a409.

[24] Pénzes, J. (2013). The Dimensions of Peripheral Areas and Their Restructuring in Central Europe. Hungarian Geographical Bulletin 62(4): 373-386.

[25] Philip, L. J. \& Shucksmith, M. (2003). Conceptualizing social exclusion in rural Britain. European Planning Studies 11(4): 461-480. DOI: 10.1080/09654310303646.

[26] Plazinić, B. R. \& Jović, J. (2014). Women and transportation demands in rural Serbia. Journal of Rural Studies, 36, 207-218. DOI: 10.1016/j.jrurstud.2014.08.002.

[27] Pospěch, P., Delín, M. \& Spěšná, D. (2009). Quality of life in Czech rural areas. Agriculture Economics-Czech, 55, 284-295.

[28] Potter, J. \& Cantarero, R. (2006). How does increasing population and diversity affect resident satisfaction? A small community case study. Environment and Behavior, 38(5), 605625. DOI: $10.1177 / 0013916505284797$.

[29] Reimer, B. (2004). Social exclusion in a comparative context. Sociologia Ruralis, 44(1), 7694. DOI: 10.1111/j.1467-9523.2004.00263.x.

[30] Requena, F. (2016). Rural-urban living and level of economic development as factors in subjective well-being. Social Indicators Research, 128(2), 693-708. DOI: 10.1007/s11205015-1051-1.

[31] Roscigno, V. J., Tomaskovic-Devey, D. \& Crowley, M. (2006). Education and the inequalities of place. Social Forces 84(4), 2121-2145.

[32] Roscigno, V. J. \& Crowley, M. L. (2001). Rurality, Institutional Disadvantage, and Achievement/Attainment. Rural Sociology 66 (2), 268-292. DOI: 10.1111/j.15490831.2001.tb00067.x.

[33] Růžička, M. (2012). Continuity or rupture? Rome/Gypsy communities in rural and urban environments under post-socialism. Journal of Rural Sociology 28(2): 81-88. DOI: 10.1016/j.jrurstud.2012.01.019.

[34] Sharkey, P. \& Faber, J. W. (2014). Where, when, why, and for whom do residential contexts matter? Moving away from the dichotomous understanding of neighborhood effects. Annual Review of Sociology, 40, 559-579. DOI: 10.1146/annurev-soc-071913-043350. 
[35] Shaw, J. M. (1979). Rural Deprivation and Planning. Norwich: Geobooks.

[36] Shucksmith, M. (2004). Young people and social exclusion in rural areas. Sociologia Ruralis 44 (1): 43-59. DOI: 10.1111/j.1467-9523.2004.00261.x.

[37] Shucksmith, M. \& Philip, L. (2000). Social Exclusion in rural areas: A literature review and conceptual framework. Aberdeen: University of Aberdeen.

[38] Shucksmith, M., Cameron, S., Merridew, T. \& Pichler, F. (2009). Urban-rural differences in quality of life across the European Union. Regional Studies, 43(10), 1275-1289. DOI: 10.1080/00343400802378750.

[39] Sikora, E. (2007). Youth from Rural Communities: Social Inequalities in Access to Education. Eastern European Countryside, 13, 111-129.

[40] Sirgy, J. M., Gao, T. \& Young, R. F. (2008). How Does Resident's Satisfaction with Community Services Influence Quality of Life (QOL) Outcomes? Applied Research in Quality of Life 3, 81-105. DOI: 10.1007/s11482-008-9048-4.

[41] Swain, N. (2016). Eastern European Rurality in a Neo-Liberal, European Union World. Sociologia Ruralis, 56(4), 574-596. DOI: 10.1111/soru.12131.

[42] Šimon, M. \& Bernard, J. (2016). Rural Idyll without Rural Sociology? Changing Features, Functions, and Research of the Czech Countryside. Eastern European Countryside 22(1), 53-68. DOI: 10.1515/eec-2016-0003.

[43] Temelová, J., Novák, L., Pospíšilová, L. \& Dvořáková, N. (2011). Každodenní život, denní mobilita a adaptační strategie obyvatel v periferních lokalitách. Sociologický časopis [Czech Sociological Review], 47(4), 831-858.

[44] Theodori, G. L. (2001). Examining the Effects of Community Satisfaction and Attachment on Individual Well-Being. Rural Sociology 66(4), 618-628. DOI: 10.1111/j.15490831.2001.tb00087.x.

[45] Tickamyer, A. R. \& Duncan, C. M. (1990). Poverty and opportunity structure in rural America. Annual Review of Sociology, 16(1), 67-86. DOI: 10.1146/annurev.so.16.080190.000435.

[46] Townsend, P. (1987). Deprivation. Journal of Social Policy, 16(2), 125-146. DOI: $10.1017 /$ S0047279400020341.

[47] Weber, B., Jensen, L., Miller, K., Mosley, J. \& Fisher, M. (2005). A critical review of rural poverty literature: Is there truly a rural effect? International Regional Science Review, 28(4), 381-414. DOI: 10.1177/0160017605278996.

[48] Winters, J. V. \& Li, Y. (2017). Urbanisation, natural amenities and subjective well-being: Evidence from US counties. Urban Studies, 54(8), 1956-1973. DOI: $10.1177 / 0042098016631918$.

Other sources

[49] Eurostat (2015). Quality of life by degree of urbanisation. Downloaded from: http://ec.europa.eu/eurostat/statistics-

explained/index.php/Quality_of_life_by_degree_of_urbanisation\#Average_satisfaction_with _accommodation.

[50] Ministry of Agriculture of the Czech Republic (2016). Chceme podporit život a podnikání $v$ malých obcích, připravujeme slevy na pojistném i zvýhodněné podnikatelské úvěry. Press release. Accessible at: http://eagri.cz/public/web/mze/tiskovy-servis/tiskovezpravy/x2016_ministr-jurecka-chceme-podporit-zivot-a.html. 